sciendo

\title{
Osarumwense Osabuohien-Irabor
}

(iD) https://orcid.org/0000-0001-8731-2557

Department of International Economics,

School of Economics,

Ural Federal University, Ekaterinburg, Russia

oosabuokhien-irabor@urfu.ru

\section{Testing for causality-in-mean and in-variance among the U.S., China, and some Africa capital markets: A CCF approach}

Accepted by Editor Ewa Ziemba | Received: July 22, 2020 | Revised: December 12, 2020; March 12, 2021; April 4, 2021 | Accepted: April 8, 2021 | Published: April 28, 2021.

(C) 2021 Author(s). This article is licensed under the Creative Commons Attribution-NonCommercial 4.0 license (https://creativecommons.org/licenses/by-nc/4.0/)

\begin{abstract}
Aim/purpose - Owing to the huge risk occasioned by negative contagion effects associated with financial market linkages, markets participants and academia have continued to examine the capital market cross country interdependence at different levels. In this paper, we examined the causal relationships among the U.S., China and some top African capital market indexes.

Design/methodology/approach - To examine the mean and variance causal effects, we estimated a univariate AR-EGARCH model for all capital market indexes. Then employed the residual-based two-step bivariate cross-correlation function (CCF) test developed by Cheung \& Ng (1996). The test statistics had a well-defined asymptotic standard distribution that was robust to distributional assumptions.

Findings - We detected both the feedback and unidirectional causality effects among African capital markets. These results show that African financial markets are still not fully integrated within the African continent. Expectedly, the results from our empirical analysis showed the existence of a unidirectional causality both in mean and variance from the U.S. and Chinese markets to African capital markets. This demonstrated that events in the U.S. and China are not irrelevant to African markets.

Research implications - Owing to the fact that knowledge of other financial markets provides adequate information about a market situation, the results from this research paper will be helpful for the policymakers of African countries in shaping their economic policies, help investors diversify investments with less risk, and international portfolio managers make portfolio allocation decisions.
\end{abstract}

Cite as: Osabuohien-Irabor, O. (2021). Testing for causality-in-mean and in-variance among the U.S., China, and some Africa capital markets: A CCF approach. Journal of Economics \& Management, 43, 131-153. https://doi. org/10.22367/jem.2021.43.07 
Originality/value/contribution - This paper examined the mean and risk dynamics of three top African, the U.S., and Chinese capital markets with their inter-dependence using the CCF approach. Furthermore, to the best of our knowledge, no previous research paper on this issue exists.

Keywords: causality-in-mean, causality-in-variance, capital market, cross-correlation function.

JEL Classification: G10, F31, C20.

\section{Introduction}

The degree of soundness of the capital market reflects the level of National Economic Development as well as other economic growth in a country (Feldman \& Wagner, 2002). This is a major indicator to measure both the financial sector and macro-economic stability. That is, the performance of a countries' stock indexes is usually employed as a proxy to assess how heathy or expanding a country's economy is. For this reason, governments, companies' stakeholders, private investors, and academia keep a close watch on capital market activities. Previous financial crises in past decades led to the debate on whether the sequences of financial distress in countries are primarily due to bad domestic macroeconomic policies or as a result of economies becoming vulnerable to negative effects occurring elsewhere, particularly other financial markets (Grant \& Wilson, 2012). The latter perspective motivated numerous empirical studies to investigate whether financial market cross-country interactions impact one another significantly. Volatility spillovers from financial markets have widely been examined in behavioral financial literature in different strands of studies, linear and nonlinear Granger causality (e.g., Rashid, 2007; Wang, Zheng, \& Zhu, 2014), frequency domain causality test (e.g., Gradojevic \& Dobardzic, 2013; Breitung \& Candelon, 2006), cointegration test (Onay \& Ünal, 2012; Ratanapakorn \& Sharma, 2002), Markov-switching VAR (Çevik, Çevik, \& Gurkan, 2012; Qiao, Li, \& Wong, 2011). Those previous studies on information flow between markets tend to investigate the causality-in-mean. However, Ross (1989) study clearly showed that beside return data, return volatility can also supply useful data for information flow. This suggests that price volatilities contain useful information with significant implication concerning market linkage. Ross (1989) seminal paper led to the emergence of several empirical studies with various methodological frameworks in both univariate and multivariate used to examine the relationship of conditional variance across financial markets. 
Whilst Granger (1969) causality test framework mainly focused on the conditional mean of the variables, Cheung \& Ng (1996) developed the CCF (cross-correlation function) approach that examines not only causality in the mean, but also in-variance. Compared to other univariate and multivariate methods, its application does not undergo simultaneous modelling. For this reason, its implementation is easy. The model framework relies on the residual estimated from the univariate model; hence it is robust to the problem associated with omission of variables. In addition to its robustness, the method has a well-defined asymptotic distribution that does not depend on the normality assumptions. Growing numbers of studies have examined financial market linkages using the residual-based approach. Toyoshima (2018) examined the causality-in-mean and in variance between the UK housing and stock markets. His results revealed a two-way causal relation between housing and stock markets in the UK. Bouri, Chen, Lien, \& Lv (2017) paper examined the relevance of oil product pricing mechanism to the Chinese market by investigating the causality between oil prices and the stock market in China using the residual-based test. Their results revealed that after the reform of March 27, 2013 causality-in-mean between the two markets strengthened, but almost disappeared after the date for the causality-in-variance. Other notable studies that have employed Cheung \& Ng (1996) test to examine the contagious effects include Boubaker \& Sebai (2009); Sultonov (2019); Nishimura, Tsutsui, \& Hirayama (2016).

In spite of the numerous drawbacks on the use of time varying model, not much has been done on the use of the two-stage residual testing approach developed by Cheung \& Ng (1996) to examine both the causality-in-mean and invariance of financial market activities. To the best of our knowledge, no literature studies exist on the use of this methodology for capital markets linkages in Africa related research. For this reason, we are motivated to add to this strand of studies by examining the causality-in-mean and in-variance among the U.S., China, and some top African capital markets using the residual-based causality test approach developed by Cheung \& Ng (1996). Results showed some top African markets influence one another in either two-way or one-way causality directions. We found evidence of unidirectional causation pattern for mean and variance running from the U.S. and Chinese markets to African markets.

The rest of the paper is structured as follows. Section 2 reviews the relevant literature studies related to CCF approach. In Section 3, we describe the methodology which includes, the data, the statistical properties of data and the econometric framework of the study. Whilst section 4 presents the research findings, 
Section 5, discusses the results of the causality relationships (in-mean and in-variance) for the five different capital markets. Finally, Section 6 summarizes the research findings as well as the concluding remarks of this research paper.

\section{Literature review}

The main intent of this paper is to explore Cheung \& $\mathrm{Ng}$ (1996) causality test to examine the linkages between leading African capital markets and major world indexes. An avalanche of literature abounds on stock market inter-linkages. However, many of these capital market inter-relationships, whether within the Africa markets or developed markets, have been examined using time varying dynamic models, particularly the GARCH model, formulated by Engle (1982) and developed by Bollerslev (1986). Using VAR-GARCH framework, Syriopoulos, Makram, \& Boubaker (2015) investigated the dynamic risk-return properties of the BRICS capital market, the time-varying correlations as well as the volatility spillover effects with the U.S. stock market. They found a significant return and volatility transmission between the U.S. and BRICS stock. Osabuohien-Irabor (2015) merged the Constant Correlation (CC) model to the AR-MEGARCH model to examine the returns and volatility spillover effects among exchange rate Naira/USD, crude oil (WTI) and the capital market. His results suggests that good news in the price of crude oil has more impacts than the bad news in NSE-30 index. Similarly, Kang \& Yoon (2020) examined the returns and volatility transmission between the Chinese market stock activities and the commodity future markets. Their empirical results found evidence of linkages from stock return to both the Chinese stock and the commodity markets. Vardar, Coşkun, \& Yelkenci (2018) used the VAR-BEKK GARCH model to examine shocks and volatility spillover effects among several stock markets such as, the U.S., UK, France, Germany, Japan, Turkey, China, South Korea, South Africa, and India. They found significant spillover effects from stock returns to the commodity returns for developed economies. Other literature on this strand of research includes, e.g., Akkoc \& Civcir (2019), Marozva (2017), Bonga-Bonga \& Hoveni (2011), Urama, Ezepue, \& Nnanwa (2017), Uyaebo, Atoi, \& Usman (2015), Osabuohien-Irabor (2020), Moon \& Yu (2010).

Another large body of literature employs the Fractionally Integrated Generalized Autoregressive Conditional Heteroskedasticity (FIGARCH) models to capture spillover effects with long memory. Whilst Mensi, Hammoudeh, Nguyen, \& Kang (2016) used the bivariate DCC-FIAPARCH model and Value- 
-at-Risk (VaR) to examine the spillover effect between the U.S. market and the BRICS countries, Sabkha, De Peretti, \& Mezzez Hmaied (2019) used the bivariate FIEGARCH model and the Bayesian co-integrated vector autoregressive model to examine the volatility spillover among thirty-three (33) sovereign Credit Default Swap (CDS) markets. The former empirical results revealed the evidence of asymmetry and long memory in the conditional volatility and significant dynamic correlations between the U.S. and the BRICS stock markets. For the latter study, their results showed that the sovereign crisis weakened the global financial and banking system more than the subprime crisis. El Abed, Boukadida, \& Jaidane (2019) study merged the Dynamic Conditional Correlation (DCC) model with the Fractionally Integrated Generalized Arch (FIGARCH) models to examine the linkages between the daily Eurozone sovereign credit default swaps (CDS) index and four financial market sectors. Their findings suggested the spillover effects of CDS index and financial market indicators. Shi \& Ho (2015); Ben Nasr, Ajmi, \& Gupta (2014); Ben Nasr, Boutahar, \& Trabelsi (2010); Kiliç (2011); Belkhouja \& Boutahary (2011), are literature studies that have also explored the Fractionally Integrated GARCH models to examine risk dynamics.

In addition to the use of time varying dynamics model to examine financial markets linkages, many other literature studies have also adopted different methodologies. For example, Atenga \& Mougoue (2020) examined the effects of international and regional shocks on African stock markets using variance decompositions in vector autoregression model introduced and developed by Diebold \& Yilmaz (2009). Their findings revealed that international and regional market shocks have heterogeneous and time-varying effects on African stock markets. Singh Kumar, Kumar, \& Nishant (2019) used the Generalized Error Variance Decomposition (GEVD) to study the squared return spillover among the pre- and post-global financial crisis of 2008 and during the crude oil crises of 2008-2009 and 2014-2015. Their results showed that return spillover connectedness is significant in some Europe and North America economies for full sample. Dewandaru, Masih, \& Masih (2017) employed the wavelet-based time and frequency decomposition framework to examine whether transmitted shocks were pure contagion or fundamental-based for four stock markets (Saudi Arabia, UAE, South Africa and Israel). They found that during the subprime crisis the shocks generated pure contagion. Giovannetti \& Velucchi (2013) used the Multiplicative Error fully inter-dependent Model (MEM) with impulse-response functions to model the relationships among the U.S., UK, China financial mar- 
kets on one hand, and some African emerging markets, such as Botswana, Kenya, Nigeria, Egypt, Tunisia, and South Africa on the other. Their findings showed that South Africa and U.S. shocks significantly affected African financial markets.

However, Cheung \& $\mathrm{Ng}$ (1996) research paper posited that the interactions between dynamics series can become a problem in the formulation of a multivariate GARCH model, and possibly lead to wrong model specification and ultimately generate misleading results. They introduced the residual-based test which does not undergo simultaneous modelling. In support of Cheung \& $\mathrm{Ng}$ (1996) test, Hafner \& Herwartz (2006) also indicated that one of the problems of the use of the Likelihood-base test within the framework of multivariate dynamics, is that the model suffers from the curse of dimensionality. Despite the numerous advantages of Cheung \& $\mathrm{Ng}$ (1996) test, only a handful of studies have examined causal effects using this method. Stolbov (2014) paper examined interdependence between CDS prices of BRICS and top EU leading economies. They employed the residual-based approach of Cheung \& $\mathrm{Ng}$ (1996) to investigate causal relationships. Their results supported the view that the EU debt crisis had limited the non-EU impact in the market. Other researchers exploring this issue include Hanabusa (2009); Bhar \& Hamori (2005). This research paper adds to the scarce strand of literature which employs the Cheung \& Ng (1996) framework to examine the contagion effect in-mean and in-variance among financial markets indexes.

\section{Research methodology}

\subsection{Data selection and description}

For more than three decades, Nigeria, South Africa, and Egypt have been ranked as the 'the largest economy in Africa' based on the strength of their currency and gross domestic product (GDP). With a GDP of 442.98 and 282.59 billion US dollars, respectively, Nigeria and South Africa account for almost half of sub-Saharan Africa's gross domestic product. Egypt is rated as a country with the second biggest GDP in Africa and the biggest in the north African region (Statista, 2021). These three countries are located in different regions of Africa and are depended on by other Africa's countries with smaller economies. Therefore, 'the booms and shrinkages' of these 'big brothers' of Africa's economies (Nigeria, South Africa, and Egypt) affect surrounding countries (Gumede, 
Oloruntoba, \& Kamga, 2020). These regional activities have fostered financial and economic integration for African countries (Awad \& Yussof, 2017; Ekpo \& Chuku, 2017). However, China and the U.S. are ranked as the two biggest single exporters of goods and services to African countries, and almost $50 \%$ of African countries' import comes from both China and the U.S. Therefore, the relationship between these countries, particularly between China/the U.S., and these large African economies, will provide useful insight for policy makers and portfolio selection.

This paper examines the causality-in-mean and in-variance among the U.S., China, and African market indexes. The African capital markets indexes are indicated by the Nigerian NGSE-30, South African JSE-40, and the Egyptian EGX-30. Whilst the American and Chinese capital markets are represented by S\&P 500 and Shanghai Stock Exchange Composite (SSE-Com), respectively. The daily closing prices of capital indexes range for the period of January $4^{\text {th }}$, 2010 to February $9^{\text {th }}, 2018$. This covers a total of 2,113 observations. All data were obtained from a known professional data service company - the Bloomberg data services (https://www.bloomberg.com). The logarithmic return series are used in the empirical analysis, and the descriptive statistics are presented in West \& Cho (1995) standard format (Table 1).

Table 1. Summary statistics

\begin{tabular}{|c|c|c|c|c|c|c|c|}
\hline \multicolumn{3}{|c|}{ Variable } & NGSE-30 & JSE-40 & EGX-30 & S\&P 500 & SSE-Com \\
\hline \multirow{12}{*}{$\begin{array}{l}\omega^{+} \\
\ddot{z} \\
\ddot{\Xi} \\
\ddot{\Xi}\end{array}$} & 1 & Mean & $\begin{array}{c}0.041 \\
(0.028)\end{array}$ & $\begin{array}{c}0.033 \\
(0.021) \\
\end{array}$ & $\begin{array}{c}0.041 \\
(0.037) \\
\end{array}$ & $\begin{array}{c}0.041 \\
(0.019)\end{array}$ & $\begin{array}{l}0.0002 \\
(0.030)\end{array}$ \\
\hline & 2 & $\begin{array}{l}\text { Standard } \\
\text { deviation }\end{array}$ & $\begin{array}{c}1.021 \\
(0.042) \\
\end{array}$ & $\begin{array}{c}1.014 \\
(0.026) \\
\end{array}$ & $\begin{array}{r}1.445 \\
(0.052) \\
\end{array}$ & $\begin{array}{c}0.915 \\
(0.039) \\
\end{array}$ & $\begin{array}{r}1.402 \\
(0.060) \\
\end{array}$ \\
\hline & 3 & Skewness & $\begin{array}{c}0.384 \\
(0.310) \\
\end{array}$ & $\begin{array}{l}-0.164 \\
(0.098) \\
\end{array}$ & $\begin{array}{l}-0.611 \\
(0.274) \\
\end{array}$ & $\begin{array}{l}-0.516 \\
(0.220) \\
\end{array}$ & $\begin{array}{l}-1.001 \\
(0.203) \\
\end{array}$ \\
\hline & 4 & $\begin{array}{l}\text { Excess } \\
\text { kurtosis }\end{array}$ & $\begin{array}{c}5.408 \\
(1.711) \\
\end{array}$ & $\begin{array}{c}1.612 \\
(0.255) \\
\end{array}$ & $\begin{array}{c}5.229 \\
(1.452)\end{array}$ & $\begin{array}{c}5.145 \\
(1.496)\end{array}$ & $\begin{array}{c}6.382 \\
(0.800)\end{array}$ \\
\hline & 5 & $\begin{array}{l}\text { Modified } \\
\text { L-B(10) }\end{array}$ & $\begin{array}{l}74.390 \\
{[0.000]} \\
\end{array}$ & $\begin{array}{c}11.117 \\
{[0.348]} \\
\end{array}$ & $\begin{array}{l}36.313 \\
{[0.000]}\end{array}$ & $\begin{array}{l}13.175 \\
{[0.214]} \\
\end{array}$ & $\begin{array}{l}11.885 \\
{[0.293]}\end{array}$ \\
\hline & 6 & $\begin{array}{l}\text { Modified } \\
\text { L-B(50) }\end{array}$ & $\begin{array}{l}164.424 \\
{[0.000]}\end{array}$ & $\begin{array}{c}39.991 \\
{[0.843]}\end{array}$ & $\begin{array}{c}69.109 \\
{[0.038]}\end{array}$ & $\begin{array}{c}70.116 \\
{[0.032]}\end{array}$ & $\begin{array}{l}66.947 \\
{[0.055]}\end{array}$ \\
\hline & 7 & $\begin{array}{l}\text { Modified } \\
\text { L-B(90) }\end{array}$ & $\begin{array}{c}213.339 \\
{[0.000]}\end{array}$ & $\begin{array}{c}79.085 \\
{[0.788]}\end{array}$ & $\begin{array}{l}110.262 \\
{[0.072]}\end{array}$ & $\begin{array}{c}110.689 \\
{[0.069]}\end{array}$ & $\begin{array}{c}123.55 \\
{[0.011]}\end{array}$ \\
\hline & 8 & Minimum & -4.631 & -4.049 & -11.117 & -6.896 & -8.873 \\
\hline & 9 & Q1 & -0.459 & -0.508 & -0.623 & -0.314 & -0.530 \\
\hline & 10 & Median & 0.007 & 0.059 & 0.069 & 0.053 & 0.055 \\
\hline & 11 & Q3 & 0.518 & 0.637 & 0.802 & 0.483 & 0.616 \\
\hline & 12 & Maximum & 8.424 & 4.679 & 7.314 & 4.632 & 5.604 \\
\hline
\end{tabular}


table 1 cont.

\begin{tabular}{|c|c|c|c|c|c|c|c|}
\hline \multicolumn{3}{|c|}{ Variable } & NGSE-30 & JSE-40 & EGX-30 & S\&P 500 & SSE-Com \\
\hline \multirow{6}{*}{$\begin{array}{l}\text { Wँ } \\
\ddot{\theta} \\
\ddot{\Xi} \\
\ddot{\Xi}\end{array}$} & 13 & Mean & $\begin{array}{c}1.045 \\
(0.086) \\
\end{array}$ & $\begin{array}{c}1.029 \\
(0.053) \\
\end{array}$ & $\begin{array}{c}2.089 \\
(0.151) \\
\end{array}$ & $\begin{array}{c}0.839 \\
(0.071)\end{array}$ & $\begin{array}{c}1.965 \\
(0.170) \\
\end{array}$ \\
\hline & 14 & $\begin{array}{l}\text { Standard } \\
\text { deviation }\end{array}$ & $\begin{array}{c}2.851 \\
(0.477) \\
\end{array}$ & $\begin{array}{c}1.948 \\
(0.126) \\
\end{array}$ & $\begin{array}{c}5.587 \\
(0.811) \\
\end{array}$ & $\begin{array}{c}2.224 \\
(0.368) \\
\end{array}$ & $\begin{array}{c}5.690 \\
(0.621) \\
\end{array}$ \\
\hline & 15 & L-B(10) & $\begin{array}{c}458.505 \\
{[0.000]} \\
\end{array}$ & $\begin{array}{c}384.710 \\
{[0.000]}\end{array}$ & $\begin{array}{c}173.544 \\
{[0.000]}\end{array}$ & $\begin{array}{c}1047.262 \\
{[0.000]}\end{array}$ & $\begin{array}{c}633.065 \\
{[0.000]} \\
\end{array}$ \\
\hline & 16 & L-B(50) & $\begin{array}{c}601.282 \\
{[0.000]}\end{array}$ & $\begin{array}{c}799.748 \\
{[0.000]}\end{array}$ & $\begin{array}{c}208.449 \\
{[0.000]}\end{array}$ & $\begin{array}{c}1808.403 \\
{[0.000]}\end{array}$ & $\begin{array}{c}1916.680 \\
{[0.000]}\end{array}$ \\
\hline & 17 & L-B(90) & $\begin{array}{c}729.294 \\
{[0.000]} \\
\end{array}$ & $\begin{array}{r}842.089 \\
{[0.000]} \\
\end{array}$ & $\begin{array}{c}225.331 \\
{[0.000]}\end{array}$ & $\begin{array}{c}2054.524 \\
{[0.000]}\end{array}$ & $\begin{array}{c}2087.921 \\
{[0.000]}\end{array}$ \\
\hline & 18 & $\operatorname{ARCH}(10)$ & $\begin{array}{c}324.470 \\
{[0.000]} \\
\end{array}$ & $\begin{array}{c}203.739 \\
{[0.000]} \\
\end{array}$ & $\begin{array}{c}150.256 \\
{[0.000]} \\
\end{array}$ & $\begin{array}{c}260.267 \\
{[0.000]}\end{array}$ & $\begin{array}{c}442.733 \\
{[0.000]}\end{array}$ \\
\hline
\end{tabular}

Note: The $S_{t}$ is the change in the daily return indexes. $S^{2}$ denotes the squared changes for returns indexes. The $p$-values of the asymptotic chi-square statistics are in brackets, shown in the lower halves of rows 5-7 and 15-18. This contains the Ljung-Box statistics and the LM conditional variance test (ARCH test). The variables in rows $1-4,13$ and 14 are the standard errors in parentheses.

The daily mean return for all indexes varies between 0.0002 to 0.041 percent. The least and highest mean return series occurs in SSE-Com and NGSE-30 respectively as shown in Table 1 (line 1) and Figure 1. The interquartile range is much less than two standard deviations (line 9 and 11). With the exception of South African JSE-40, other return indexes have excess kurtosis (line 4) much greater than two and significantly different from zero. There is evidence of skewness in the returns index of EGX-30, S\&P 500 and SSE-Com. Besides, some returns series also showed evidence of leptokurtic (line 3 and 4). The changes in the standard deviation (line 2) for all market indexes is about $1 \%$, and EGX-30 exhibit higher volatility return. 
Figure 1. The daily returns and series of markets indexes
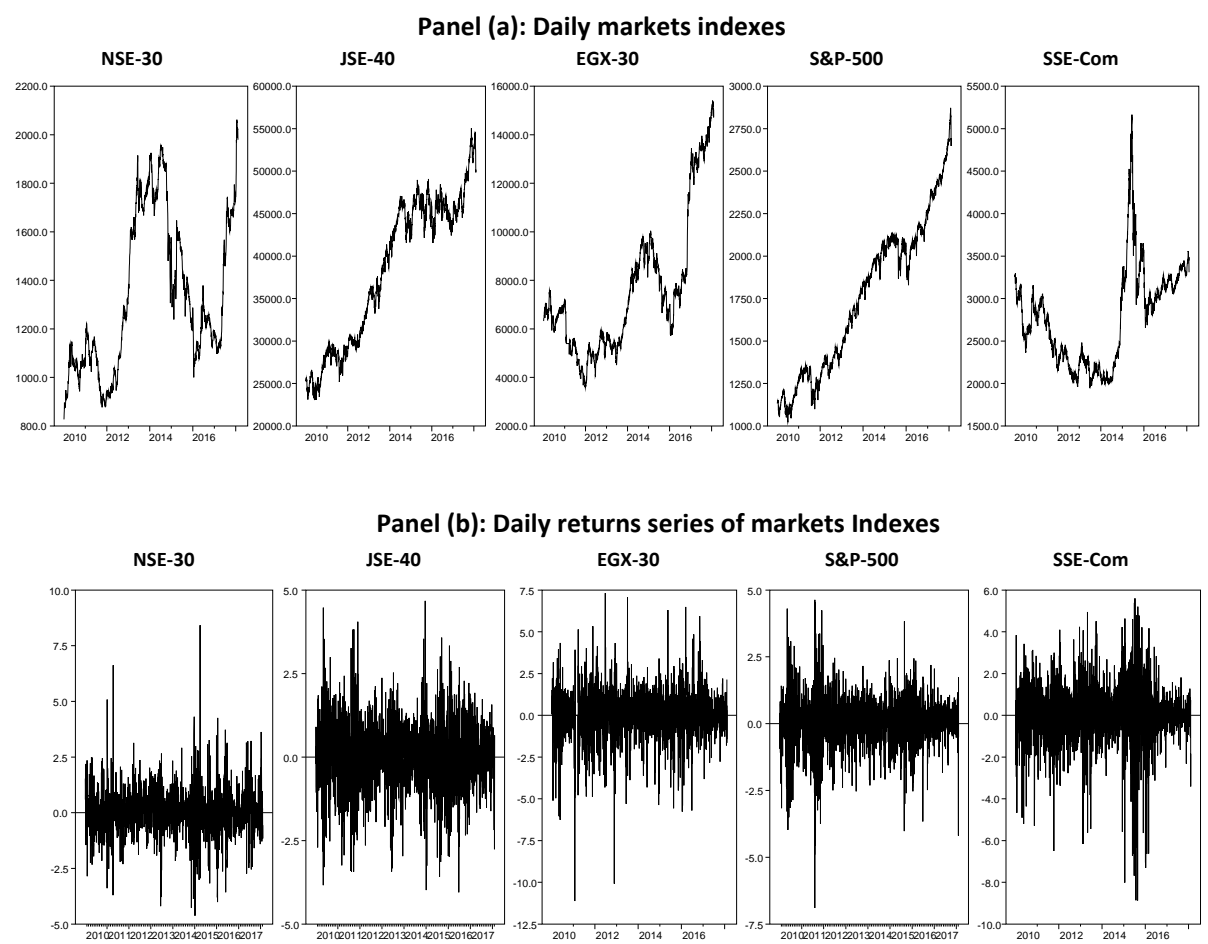

\subsection{Statistical properties of data}

We constructed West \& Cho (1995) standard empirical table (Table 1) to illustrate our empirical results. Whilst panel A of Table 1 contains the summary statistics of historical returns variables, panel B shows the squared changes for returns indexes. The Ljung-Box test for return shown in Table 1, line 5-7 initially appears uncorrelated, particularly JSE-40 and S\&P 500. But the results in panel $\mathrm{B}$ line 15-18 show that the p-values are significantly not different from zero, indicating the presence of serial correlation and conditional heteroskedasticity. Thus, we employed the EGARCH model discussed in section 3.2 to attain homoskedasticity assumptions. The properties of our variables are consistent with financial time series variables, particularly stock prices and exchange rates West \& Cho (1995); Diebold \& Nerlove (1989). Figure 1, panel (a) and (b), shows the plots for African capital markets, the American market and the Chinese market indexes, and returns. Apart from S\&P 500 that had few volatile 
periods, the other capital markets experienced a very high volatility period. It is of note that the forces behind these volatilities are usually not due to domestic factors or shocks, but due to events taking place in other stock markets or other factors. All indexes show a calm period beginning from 2016 (Figure 1).

\subsection{Econometric framework}

\subsubsection{Exponential GARCH model}

It is well known that most financial time series returns exhibit nonnormality and ARCH effect. Examining causality-in-mean and causality-in-variance effects is important for financial market variables (e.g., stock returns and exchange rates) because it reveals the general pattern of volatility spillover between (among) financial markets. In this section, we described the two-step methodological framework proposed by Cheng \& $\mathrm{Ng}$ (1996).

Causality-in-variance provides an insight into the dynamics and characteristics of financial market prices. Hence, Cheung \& $\mathrm{Ng}$ (1996) asserted that changes in variance reflect the arrival of new information, and the extent to which the market evaluates and assimilates new information. Knowledge of such information can be used to formulate better econometric models. Thus, this research paper investigates the presence of a causal relation in mean and variance among capital market returns and variances. The first step of the CCF causality-in-mean/variance test is to estimate a univariate Autoregressive-Generalized Autoregressive Conditional Heteroskedasticity $\operatorname{AR}(k)-E G A R C H ~(p, q)$ process. However, the exponential GARCH (EGARCH) model proposed by Nelson (1991) is said to perform better than the vanilla GARCH model specifications. Thus, the innovations from the returns are derived from the AR-EGARCH model:

$$
\begin{gathered}
R_{t}=a_{0}+\sum_{i=1}^{k} a_{i} R_{t-1}+\varepsilon_{t} \quad \varepsilon_{t} / t-1 \sim N\left(0, h_{t}\right) \\
\ln \left(h_{t}\right)=\varpi+\sum_{i=1}^{q} \alpha, g\left(Z_{t-1}\right)+\sum_{j=1}^{p} \gamma_{j} \ln \left(h_{t-j}\right) \\
g\left(z_{t}\right)=\theta z_{t}+\gamma\left(\left|z_{t}\right|-E\left|z_{t}\right|\right) \\
z_{t}=\varepsilon_{t} / \sqrt{h_{t}}
\end{gathered}
$$




\subsubsection{The cross-correlation function}

The two-step procedure for the (cross-correlation function) CCF test is as follows: first, we estimated a univariate EGARCH model specification which allows for time variation in both conditional means and conditional variances for each market indexes, as discussed in Subsection 3.2. Then we obtained the squared residuals of each estimated models, hence the squared residuals standardized by conditional variances series was then constructed. Thereafter, we employed the cross-correlation function to test the null hypothesis of no causality in-variance and/or the null hypothesis of causality in mean using the squared-standardized residuals. This procedure would help to detect the existence of any interaction between causality-in-mean and causality-in-variance. Following Cheung \& Ng (1996), we considered two stationary and ergodic time series $Z_{1}$ and $Z_{2}$ as well as two information sets in a bivariate model, defined by:

$$
I_{t}=\left\{Z_{1, t-j}, j \geq 0\right\} \text { and } J_{t}=\left\{Z_{1, t-j}, Z_{2, t-j}, j \geq 0\right\}
$$

Then $Z_{2}$ is said to cause $Z_{1, t+1}$ in-variance if:

$$
E\left\{\left(Z_{1, t+1}-\mu_{x, t+1}\right)^{2} / I_{t}\right\} \neq E\left\{\left(Z_{1, t-1}-\mu_{x, t+1}\right)^{2} / J_{t}\right\}
$$

In equation (5), $\mu_{x, t+1}$ is defined as the mean of $Z_{1, t+1}$ conditional on the information set $I_{t}$. For feedback in-variance to take place we require to occur if $Z_{1}$ causes $Z_{2}$ and $Z_{2}$ causes $Z_{1}$ if:

$$
E\left\{\left(Z_{1, t+1}-\mu_{x, t+1}\right)^{2} / I_{t}\right\} \neq E\left\{\left(Z_{1, t-1}-\mu_{x, t+1}\right)^{2} / J_{t}+Z_{2, t+1}\right\}
$$

We define causality in mean running from $Z_{2}$ to $Z_{1, t+1}$ if:

$$
E\left\{Z_{1, t+1} / I_{t}\right\} \neq E\left\{Z_{1, t+1} / J_{t}\right\}
$$

In order to test for the causality-in-mean and causality-in-variance for any returns on financial assets, we imposed an additional structure in equation (5) to (7). Let us assume that the mean equations for series $Z_{1}$ causes $Z_{2}$ can be written with the mathematical formulation:

$$
Z_{1}=\mu_{x, t}+\sqrt{h_{1, t} \varepsilon_{t}} \text { and } Z_{2}=\mu_{x, t}+\sqrt{h_{2, t} \zeta_{t}}
$$


$\varepsilon_{t}$ and $\zeta_{t}$ are taken to represent two independent white noise processes with zero mean and unit variance. However, the conditional mean and variances are written as:

$$
\begin{gathered}
\mu_{\omega, t}=\sum_{i=0}^{\infty} \varphi_{\omega, i}\left(\theta_{\omega, h}\right) \omega_{t-1} \\
\left.h_{\omega, t}=\varphi_{\omega, i}+\sum_{i=0}^{\infty} \varphi_{\omega, i}\left(\theta_{\omega, h}\right)\left(\omega_{t-1}-\mu_{\omega, t-1}\right)^{2}-\varphi_{\omega, 0}\right\}
\end{gathered}
$$

where $\theta_{\omega, h}$ is a parameter vector of dimensions $p_{\omega, h} \times 1$. Furthermore, we define $\Omega=\mu, h: \varphi_{\omega, i}\left(\theta_{\omega, h}\right)$ and $\varphi_{\omega, i}\left(\theta_{\omega, h}\right)$ as unit functions of $\theta_{\omega, \mu}$ and $\theta_{\omega, h}$, and $\omega=Z_{1}, Z_{2}$. Equation (8) and (9) underline model specifications of time series including the autoregressive moving of average models for the mean and the GARCH models for the variance. The next stage of this causality methodology is to define the squared standardized residuals for series $Z_{1, t}$ and $Z_{2, t}$. These are given as:

$$
\begin{aligned}
& U_{t}=\left(\left(Z_{1, t}-\mu_{Z_{1, t}}\right)^{2} / h_{Z_{1, t}}\right)=\varepsilon_{t}^{2} \\
& V_{t}=\left(\left(Z_{2, t}-\mu_{Z_{2, t}}\right)^{2} / h_{Z_{2, t}}\right)=\zeta_{t}^{2}
\end{aligned}
$$

$\varepsilon_{t}$ and $\zeta_{t}$ being the standardized residuals. We indicate $r_{U V}(k)$ as the sample cross-correlation of the squared standardized residual series and $r_{\varepsilon \zeta}(k)$ as the sample cross-correlation of the standardized residual series at time lag $k$. The quantities $r_{U V}(k)$ and $r_{\varepsilon \zeta}(k)$ from equations (10) and (11) are used to test causality-in-variance and causality-in-mean respectively in the framework of the CCF methodology. The hypothesis to be tested is,

$H_{0}$ : No causality at all lags Vs.

$H_{1}$ : Presence of causality at some lag $k$.

First, we test the null hypothesis that there is no causality-in-variance using the following statistic:

$$
\sqrt{T^{*} r_{u v}(k)}
$$


In equation (13) we also test the null hypothesis that there is no causality-in-variance at lag $k$ using the following statistic:

$$
\sqrt{T^{*} r_{\varepsilon \zeta}(k)}
$$

\section{Research findings}

Panel (b) of Figure 1 shows high volatilities for all capital markets. Whilst the South African JSE-40 volatility appears higher than the other African markets, the Chinese SSE-Com index showed more volatility than the U.S.' S\&P 500. Research data information shows that the South African market seems more volatile than the other two African markets. The Chinese market seems riskier than the U.S. markets. Because higher volatilities could lead to a declining market, both JSE-40 and the SSE.Com might experience low investments within the period examined. For causal effects in the mean, results indicate a feedback contemporaneous causality for both the Nigerian and Egyptian's markets. The South African market neither showed Granger cause in-mean of the two other African markets nor the international markets (U.S. and China). The Nigerian and Egyptian markets also showed Granger cause of the South African JSE-40 market in unidirectional pattern (Table 2).

Table 2. Causality-in-mean test

\begin{tabular}{|c|l|c|c|c|c|}
\hline \multirow{2}{*}{ Countries } & \multirow{2}{*}{ Causality Directions } & \multicolumn{4}{|c|}{ Lags } \\
\cline { 2 - 6 } & & $\mathbf{k}=\mathbf{3 . 0}$ & $\mathbf{k}=\mathbf{6 . 0}$ & $\mathbf{k}=\mathbf{9 . 0}$ & $\mathbf{k = 1 2 . 0}$ \\
\hline \multirow{4}{*}{$\begin{array}{c}\text { Nigeria } \\
\text { (NGSE-30) }\end{array}$} & NGSE-30 $\rightarrow$ JSE-40 & $472.001^{*}$ & $613.002^{*}$ & $691.352^{*}$ & $883.022^{*}$ \\
\cline { 2 - 6 } & NGSE-30 $\rightarrow$ EGX-30 & $232.000^{*}$ & $275.000^{*}$ & $465.000^{*}$ & $513.000^{*}$ \\
\cline { 2 - 6 } & NGSE-30 $\rightarrow$ S\&P 500 & -73.870 & -21.869 & 2.514 & -329.036 \\
\cline { 2 - 6 } & NGSE-30 $\rightarrow$ SSE-Com & 84.500 & -65.500 & 2.110 & 63.400 \\
\hline \multirow{4}{*}{$\begin{array}{c}\text { South Africa } \\
(\text { JSE-40) }\end{array}$} & JSE-40 $\rightarrow$ EGX-30 & -0.295 & -94.218 & -34.378 & -125.638 \\
\cline { 2 - 6 } & JSE-40 $\rightarrow$ NGSE-30 & -166.483 & -131.851 & -67.510 & -171.047 \\
\cline { 2 - 6 } & JSE-40 $\rightarrow$ S\&P 500 & 11.917 & -133.097 & -145.374 & -124.836 \\
\cline { 2 - 6 } & JSE-40 $\rightarrow$ SSE-Com & -26.983 & 6.233 & -54.578 & -28.271 \\
\hline \multirow{4}{*}{$\begin{array}{c}\text { Egypt } \\
(\text { EGX-30) }\end{array}$} & EGX-30 $\rightarrow$ NGSE-30 & $25.400^{*}$ & $31.700^{*}$ & $184.000^{*}$ & $184.000^{*}$ \\
\cline { 2 - 6 } & EGX-30 $\rightarrow$ JSE-40 & $285.276^{*}$ & $400.814 *$ & $543.548^{*}$ & $515.466^{*}$ \\
\cline { 2 - 6 } & EGX-30 $\rightarrow$ S\&P 500 & 83.442 & 44.605 & 14.875 & -17.157 \\
\cline { 2 - 6 } & EGX-30 $\rightarrow$ SSE-Com & 209.000 & 197.000 & 344.000 & 307.000 \\
\hline
\end{tabular}


table 2 cont.

\begin{tabular}{|c|l|c|c|c|c|}
\hline \multirow{2}{*}{ Countries } & \multicolumn{2}{|c|}{ Causality Directions } & \multicolumn{4}{|c|}{ Lags } \\
\cline { 2 - 6 } & & $\mathbf{k}=\mathbf{3 . 0}$ & $\mathbf{k}=\mathbf{3 . 0}$ & $\mathbf{k}=\mathbf{3 . 0}$ & $\mathbf{k}=\mathbf{3 . 0}$ \\
\hline \multirow{4}{*}{$\begin{array}{c}\text { U.S. } \\
\text { (S\&P 500) }\end{array}$} & S\&P 500 $\rightarrow$ JSE-40 & $456.915^{*}$ & $402.251^{*}$ & $315.365^{*}$ & $281.007^{*}$ \\
\cline { 2 - 6 } & S\&P 500 $\rightarrow$ NGSE-30 & $531.060^{*}$ & $769.850^{*}$ & $769.850^{*}$ & $927.416^{*}$ \\
\cline { 2 - 6 } & S\&P 500 $\rightarrow$ EGX30 & $451.674^{*}$ & $533.638^{*}$ & $610.361^{*}$ & $632.885^{*}$ \\
\cline { 2 - 6 } & S\&P 500 $\rightarrow$ SSE-Com & $391.707^{*}$ & $408.823^{*}$ & $398.659^{*}$ & $421.902^{*}$ \\
\hline \multirow{4}{*}{$\begin{array}{c}\text { China } \\
(\text { SSE-Com) }\end{array}$} & SSE-Com $\rightarrow$ NGSE-30 & -128.000 & $46.900^{*}$ & $104.000^{*}$ & -22.800 \\
\cline { 2 - 6 } & SSE-Com $\rightarrow$ EGX-30 & $77.100^{*}$ & $157.000^{*}$ & $200.000^{*}$ & $238.000^{*}$ \\
\cline { 2 - 6 } & SSE-Com $\rightarrow$ JSE-40 & $219.519^{*}$ & $218.505^{*}$ & $218.568^{*}$ & $207.475^{*}$ \\
\cline { 2 - 6 } & SSE-Com $\rightarrow$ S\&P 500 & -73.680 & $30.976^{*}$ & -21.552 & $42.471^{*}$ \\
\hline
\end{tabular}

* Indicates significant causality relationship.

$\rightarrow$ Indicates capital markets causality direction in $\mathrm{k}$ lags.

Table 3. Causality-in-variance test

\begin{tabular}{|c|c|c|c|c|c|}
\hline \multirow{2}{*}{ Countries } & \multirow{2}{*}{ Causality Directions } & \multicolumn{4}{|c|}{ Lags } \\
\hline & & $k=3.0$ & $k=6.0$ & $k=9.0$ & $k=12.0$ \\
\hline \multirow{4}{*}{$\begin{array}{c}\text { Nigeria } \\
\text { (NGSE-30) }\end{array}$} & NGSE-30 $\rightarrow$ JSE-40 & $317.000^{*}$ & $247.000 *$ & $226.000 *$ & $163.000 *$ \\
\hline & NGSE-30 $\rightarrow$ EGX-30 & $95.100^{*}$ & $31.700 *$ & -33.800 & -86.000 \\
\hline & NGSE-30 $\rightarrow$ S\&P 500 & -6.340 & 106.000 & 21.100 & 42.300 \\
\hline & NGSE-30 $\rightarrow$ SSE-Com & -63.400 & 177.000 & 289.000 & 300.000 \\
\hline \multirow{4}{*}{$\begin{array}{c}\text { South Africa } \\
\text { (JSE-40) }\end{array}$} & JSE-40 $\rightarrow$ NGSE-30 & $93.000^{*}$ & $304.000^{*}$ & $262.000^{*}$ & $205.000 *$ \\
\hline & JSE-40 $\rightarrow$ EGX-30 & $16.700 *$ & $294.000 *$ & $230.000 *$ & $82.400 *$ \\
\hline & JSE-40 $\rightarrow$ S\&P 500 & 34.083 & 132.421 & 222.329 & -60.157 \\
\hline & JSE-40 $\rightarrow$ SSE-Com & 211.000 & 319.000 & 397.000 & 488.000 \\
\hline \multirow{4}{*}{$\begin{array}{c}\text { Egypt } \\
(\text { EGX-30) }\end{array}$} & EGX-30 $\rightarrow$ JSE-40 & $33.800^{*}$ & $87.100^{*}$ & $256.000^{*}$ & $27.300^{*}$ \\
\hline & EGX-30 $\rightarrow$ NGSE-30 & $35.500^{*}$ & -1.690 & 61.700 & 95.700 \\
\hline & EGX-30 $\rightarrow$ SSE-Com & -90.900 & -108.000 & -42.300 & 4.230 \\
\hline & EGX-30 $\rightarrow$ S\&P 500 & 169.000 & 133.000 & 150.000 & 2.320 \\
\hline \multirow{4}{*}{$\begin{array}{c}\text { U.S. } \\
\text { (S\&P 500) }\end{array}$} & $\mathrm{S} \& \mathrm{P} 500 \rightarrow$ EGX30 & $108.000 *$ & $213.000^{*}$ & $270.000^{*}$ & $469.000 *$ \\
\hline & S\&P $500 \rightarrow$ JSE-40 & $290.41^{*}$ & $483.750 *$ & $591.787 *$ & $647.866 *$ \\
\hline & S\&P $500 \rightarrow$ NGSE-30 & $211.000 *$ & $135.000^{*}$ & $120.000^{*}$ & $44.400^{*}$ \\
\hline & S\&P $500 \rightarrow$ SSE-Com & $90.077^{*}$ & $225.330^{*}$ & $410.873^{*}$ & $418.648^{*}$ \\
\hline \multirow{4}{*}{$\begin{array}{c}\text { China } \\
\text { (SSE-Com) }\end{array}$} & SSE-Com $\rightarrow$ EGX-30 & $41.000^{*}$ & $189.000^{*}$ & $240.000^{*}$ & $330.000 *$ \\
\hline & SSE-Com $\rightarrow$ JSE-40 & 06.340 & $27.500^{*}$ & $239.000^{*}$ & $397.000 *$ \\
\hline & SSE-Com $\rightarrow$ NGSE-30 & $42.300 *$ & -35.900 & $163.000^{*}$ & $177.000 *$ \\
\hline & SSE-Com $\rightarrow$ S\&P 500 & $325.106^{*}$ & $372.035^{*}$ & $313.738^{*}$ & $461.098 *$ \\
\hline
\end{tabular}

* Indicates significant causality relationship.

$\rightarrow$ Indicates capital markets causality direction in $\mathrm{k}$ lags.

However, Table 3 shows the results for causality-in-variance for all markets. This research paper detects a bidirectional causality-in-variance flows between the Nigerian and South African market on one hand, and the South African and Egyptian markets on the other. Nevertheless, no causality exists between 
the Nigerian and Egyptian capital market. These results show that there is some interdependence among the three African leading capital markets. Nevertheless, both the U.S. and Chinese markets Granger cause the Africa capital market inmean and in-variance. The Chinese market appears not to Granger cause the U.S. market in-mean, but it certainly Granger causes in-variance. However, the U.S. market Granger causes the Chinese market both in-mean and in-variance.

\section{Discussion}

\subsection{The univariate EGARCH model}

Table 4, panel A and B, shows the correlation and covariance matrix, respectively, between the different capital markets based on their performance for over seven (7) years' periods. The correlation and covariance matrix indicate the relationship of two capital market variables whenever one variable changes. If two capital markets have positive covariance, both markets are likely to move in the same direction when responding to market conditions. As shown in Table 4, panel A, the magnitude of the correlation coefficients is positively weak. This indicates a general positive correlation among African markets, the U.S., and the Chinese capital markets. Nevertheless, only South African JSE-40 seems to be moderately correlated with the U.S. S\&P 500. Similarly, the covariance analysis in panel B of Table 4, confirms panel A results - that all the African market indexes move in the same direction.

Table 4. Correlation matrix for capital markets indexes

\begin{tabular}{|l|c|c|c|c|c|}
\hline \multicolumn{1}{|c|}{ Variables } & NGSE-30 & JSE-40 & EGX-30 & S\&P 500 & SSE-Com \\
\hline Panel A: Correlation matrix & & & & \\
\hline NGSE-30 & 1.000 & 0.053 & 0.069 & 0.014 & 0.045 \\
\hline JSE-40 & & 1.000 & 0.140 & 0.444 & 0.193 \\
\hline EGX-30 & & & 1.000 & 0.093 & 0.092 \\
\hline S\&P500 & & & 1.000 & 0.136 \\
\hline SSE-Com & & & & 1.000 \\
\hline Panel B: Covariance matrix & 1.000 & & & & \\
\hline NSE-30 & 0.054 & 1.000 & & & \\
\hline JSE-40 & 0.101 & 0.204 & 1.000 & & \\
\hline EGX-30 & 0.011 & 0.411 & 0.121 & 1.000 & \\
\hline S\&P500 & 0.065 & 0.275 & 0.186 & 0.175 & 1.000 \\
\hline SSE-Com & & & & \\
\hline
\end{tabular}


To test the causality-in-mean and in-variance, we employed the univariate EGARCH $(1,1)$ model and the results are shown in Table 5. The parameter $\beta$ indicates the persistence in volatility with a finite unconditional variance. The estimated coefficients of alpha $(\alpha)$ and beta $(\beta)$ for all capital markets are positive and statistically significant at $1 \%$ level. While $\mathrm{Q}(10)$ is a test statistic for the null hypothesis that there is no autocorrelation up to order 10 for the standardized residuals, the $\mathrm{ARCH}(10)$ tests the null hypothesis that the squared residuals are a sequence of white noise, i.e., the residuals are homoscedastic. To check the adequacies of the AR-EGARCH $(1,1)$ model, both tests were conducted, and the results are shown in Table 5. The Ljung-Box serial correlation test $Q(10)$ and $\mathrm{ARCH}(10)$ tests are statistically not significant at conventional $1 \%$ and $5 \%$ level. These results clearly validate empirically the use of the EGARCH $(1,1)$ model to describe the first and second moments tests of flows of causality. EGX-30 and S\&P 500 have the least and highest maximum log-likelihood values, respectively, with the shape parameter $\delta$ (or degrees of freedom) of the innovations (residuals probability distribution function greater than one for all the markets).

Table 5. AR-EGARCH $(1,1)$ model

\begin{tabular}{|c|c|c|c|c|c|}
\hline Parameter & NGSE-30 & JSE-40 & EGX-30 & S\&P 500 & SSE-Com \\
\hline Constant & $\begin{array}{c}0.007 \\
{[0.576]}\end{array}$ & $\begin{array}{c}0.055 \\
{[0.000]}\end{array}$ & $\begin{array}{c}0.041 \\
{[0.000]}\end{array}$ & $\begin{array}{c}0.076 \\
{[0.000]}\end{array}$ & $\begin{array}{c}0.051 \\
{[0.000]}\end{array}$ \\
\hline$A R(1)$ & $\begin{array}{c}0.255 \\
{[0.000]} \\
\end{array}$ & $\begin{array}{r}-0.009 \\
{[0000]}\end{array}$ & $\begin{array}{c}0.188 \\
{[0.000]}\end{array}$ & $\begin{array}{l}-0.056 \\
{[0.000]} \\
\end{array}$ & $\begin{array}{l}-0.013 \\
{[0.000]}\end{array}$ \\
\hline$A R(2)$ & $\begin{array}{l}-0.001 \\
{[0.833]}\end{array}$ & $\begin{array}{l}-0.071 \\
{[0.000]}\end{array}$ & $\begin{array}{l}-0.029 \\
{[0.211]}\end{array}$ & $\begin{array}{l}-0.010 \\
{[0.689]}\end{array}$ & $\begin{array}{l}-0.001 \\
{[0.050]}\end{array}$ \\
\hline$\omega$ & $\begin{array}{l}-0.370 \\
{[0.000]}\end{array}$ & $\begin{array}{l}-0.138 \\
{[0.000]}\end{array}$ & $\begin{array}{l}-0.224 \\
{[0.000]}\end{array}$ & $\begin{array}{l}-0.249 \\
{[0.000]}\end{array}$ & $\begin{array}{l}-0.091 \\
{[0.000]}\end{array}$ \\
\hline$\alpha$ & $0.444[0.000]$ & $\begin{array}{c}0.177 \\
{[0.000]} \\
\end{array}$ & $\begin{array}{c}0.403 \\
{[0.000]} \\
\end{array}$ & $\begin{array}{c}0.314 \\
{[0.000]} \\
\end{array}$ & $\begin{array}{c}0.132 \\
{[0.000]}\end{array}$ \\
\hline$\beta$ & $0.856[0.000]$ & $\begin{array}{c}0.972 \\
{[0.000]} \\
\end{array}$ & $\begin{array}{c}0.875 \\
{[0.000]} \\
\end{array}$ & $\begin{array}{c}0.955 \\
{[0.000]} \\
\end{array}$ & $\begin{array}{c}0.992 \\
{[0.000]} \\
\end{array}$ \\
\hline$\delta$ & $1.626[0.000]$ & $\begin{array}{c}1.359 \\
{[0.000]}\end{array}$ & $\begin{array}{c}1.820 \\
{[0.000]}\end{array}$ & $\begin{array}{c}1.777 \\
{[0.000]}\end{array}$ & $\begin{array}{c}1.990 \\
{[0.000]}\end{array}$ \\
\hline $\mathbf{Q}(\mathbf{1 0})$ & $\begin{array}{c}0.003 \\
{[1.000]} \\
\end{array}$ & $\begin{array}{c}0.020 \\
{[1.000]} \\
\end{array}$ & $\begin{array}{c}0.030 \\
{[1.000]} \\
\end{array}$ & $\begin{array}{c}0.020 \\
{[1.000]} \\
\end{array}$ & $\begin{array}{c}0.008 \\
{[1.000]} \\
\end{array}$ \\
\hline $\operatorname{ARCH}(10)$ & $0.749[0.678]$ & $\begin{array}{c}0.726 \\
{[0.700]}\end{array}$ & $\begin{array}{c}0.442 \\
{[0.926]}\end{array}$ & $\begin{array}{c}0.989 \\
{[0.450]}\end{array}$ & $\begin{array}{c}0.847 \\
{[0.583]}\end{array}$ \\
\hline Loglikehood & -2623.396 & -2858.429 & -3451.482 & -2333.481 & -3194.907 \\
\hline AIC & 4.446 & 3.944 & 5.190 & 4.281 & 4.433 \\
\hline SBC & 4.481 & 3.974 & 5.220 & 4.310 & 4.463 \\
\hline
\end{tabular}

Note: The Q(10) values indicates the Ljung-Box serial correlation test values for the return. $\omega$ is the constant term in the GARCH variance model, $\alpha$ is the lagged squared variance $(\mathrm{ARCH})$ term, and $\beta$ is the lagged variance $(\mathrm{GARCH})$ term. The ARCH (10) shows heteroskedasticity test results at lag10. 


\subsection{Testing for causality-in-mean and in-variance}

The second step procedure of Cheung \& Ng (1996) two-step bivariate CCF test, is to detect causality-in-mean and causality-in-variance from the calculated residual and squared residual respectively. Whilst Granger $(1969,1980)$ causality test focuses only on the changes in the mean of two financial variables, the causality-in-variance examines the conditional volatility dependence between the two variables. The standardized and squared standardized innovations in equations and estimated in Table 5 were used in testing the causality-in-mean and in-variance, respectively. The sample cross-correlation and squared standardized innovation are estimated at lag $\mathrm{k}=3,6,9$ and 12, and the results are indicated in Tables 2 and 3. The causality-in-mean test results in Table 2 present that there is feedback effects between the pair of NSE-30 and EGX-30 price series. This shows that both the Nigerian and Egyptian market are interdependent. That is, major happenings in Nigeria can impact the Egyptian capital market and vice versa. However, this is not the case for the South African market which does not influence the two other Africa markets used in this research paper.

The American and the Chinese markets were found to Granger cause African markets in returns. The cross-correlation of the squared standardized residual also reveals evidence of unidirectional causation pattern of variance from both American and the Chinese markets to African markets. Unlike in causality-in-mean, the South African JSE-40 has a feedback in-variance between pairs of Nigerian NGSE-30 and Egyptian EGX-30. There is also evidence of feedback in variances for the American S\&P 500 and the Chinese SSE-Com.

\section{Conclusions}

This research paper examined the causal relationship among the U.S., China and some African capital markets. For African markets, we investigated the three biggest capital markets in Africa, which include the Nigerian capital market, the South African capital market, and the Egyptian capital market. The American and Chinese indexes are S\&P 500 and Shanghai capital exchange, respectively. The two-step bivariate residual-based test developed by Cheung \& Ng (1996) was used to examine markets linkages for causality-in-mean and causality-in-variance. While causality-in-mean focuses on changes in-mean returns of series, causality-in-variance examines the conditional volatility between two markets. 
This research paper documented that the America's capital market, which has the largest capital market in the world, granger causes the three major African markets, both in-mean and in-variance. China-African capital market relations also appear to be similar to the U.S.-African markets causality results. These results confirmed Giovannetti \& Velucchi (2013) and Guo \& Ibhagui (2019) studies that the conditional mean returns and volatility of African capital markets are influenced by global indexes, such as the U.S. and China markets. The residual-based causality results might not be unconnected with the U.S. and China several bilateral trade partnerships and investments between these two countries and African countries. For example, while the U.S. remains the biggest investors in African countries, China has major investments in 46 out of 54 African countries. Moon \& Yu (2010) study also corroborates our results on bidirectional causality-in-variance relations for both the American and Chinese capital markets. However, Bissoondoyal-Bheenick, Brooks, Wei, \& Hung (2018) FIVAR model found that the U.S. market index granger causes the Chinese index in a unidirectional causality.

In addition, the top African capital markets are found to influence one another in either bidirectional or unidirectional causality. There is feedback causality-in-variance between Nigerian and South African markets indexes, but Phume \& Bonga-Bonga (2018) paper which employed an AVAR-GARCH model found a unidirectional causality running from South Africa to Nigeria. Furthermore, to the best of our knowledge, this research paper is the first to examine and document empirically the contagion effects between the Nigerian and Egyptian capital markets. We found no causality-in-variance running from both sides of the markets. This result confirms the near absence of bilateral trades between Nigeria and Egypt. However, a feedback causality-in-variance is detected flowing from the South African market to the Egyptian market and vice versa.

Owing to the fact that investors are risk averse and not sure of market situation (mean and volatility), this paper provides a causality framework of market investment alternatives among the America, Chinese, and African capital markets. For this reason(s), results of this empirical analysis have considerable implication for investors, portfolio managers and policy makers, in the interpretation and selection of portfolio investments as well as making timely asset allocation decisions. Besides, it provides market participants with a clear understanding of African capital markets interdependence over a period of time. Despite the flexibility and numerous advantages of Cheung \& Ng (1996) framework, its inability to simultaneously test several combinations of several 
variables is one of its major drawbacks. Hence, this research paper employed few variables (NGSE-30, JSE-40, EGX-30, SSE-Com and S\&P 500) to examine the spillover effects among the U.S., China and some top African capital markets.

Whilst this research paper focused on the application of Cheung \& $\mathrm{Ng}$ (1996) residual-based causality tests to examine the causal effects of American, Chinese, and African capital markets, future research could employ this methodology to: (i) re-examine other cross-regional financial market spillover; (ii) examine volatility transmitted at the industries level of related countries, as this could also help select the appropriate portfolio.

\section{References}

Akkoc, U., \& Civcir, I. (2019). Dynamic linkage between strategic commodities and stock market in Turkey: Evidence from SVAR-DCC-GARCH model. Resources Policy, 62, 231-239. https://doi.org/10.1016/j.resourpol.2019.03.017

Atenga, E. M. E., \& Mougue, M. (2020). Return and volatility spillover to African equity markets and their determinants. Empirical Economics. Retrieved from https:// link.springer.com/article/10.1007/s00181-020-01881-9

Awad, A., \& Yussof, I. (2017). Africa's economic regionalism: Is there any other obstacle? Journal of Economic Studies, 44(3), 344-361. https://doi.org/10.1108/JES-022016-0039

Bollerslev, T. (1986, April). Generalized autoregressive conditional heteroskedasticity. Journal of Econometrics, 31(3), 307-327. https://doi.org/10.1016/0304-4076(86) 90063-1

Bouri, E., Chen, Q., Lien, D., \& Lv, X. (2017, March). Causality between oil prices and the stock market in China: The relevance of the reformed oil product pricing mechanism. International Review of Economics and Finance, 48(C), 34-48. https:// doi.org/10.1016/j.iref.2016.11.004

Belkhouja, M., \& Boutahary, M. (2011, May). Modeling volatility with time varying FIGARCH models. Economic Modelling, 28(3), 1106-1116. https://doi.org/10.1016/ j.econmod.2010.11.017

Ben Nasr, A., Ajmi, A. N., \& Gupta, R. (2014). Modelling the volatility of the Dow Jones Islamic Market World Index using a fractionally integrated time varying GARCH (FITVGARCH) model. Applied Financial Economics, 24(14), 993-1004. https://doi.org/10.1080/09603107.2014.920476

Ben Nasr, A., Boutahar, M., \& Trabelsi, A. (2010). Fractionally integrated time varying GARCH model. Statistical Methods and Application, 19(3), 399-430. https:// doi.org/10.1007/s10260-010-0131-2 
Bhar, R., \& Hamori, S. (2005, May). Causality in variance and the type of traders in crude oil futures. Energy Economics, 27(3), 527-539. https://doi.org/10.1016/ j.eneco.2004.12.003

Bissoondoyal-Bheenick, E., Brooks, R., Wei, C., \& Hung, X. D. (2018). Volatility spill-over between the US, Chinese and Australian Stock Markets. Australian Journal of Management, 43(2). https://doi.org/10.1177/0312896217717305

Bonga-Bonga, L., \& Hoveni, J. (2011). Volatility spillovers between the equity market and foreign exchange market in South Africa (Working Papers, No. 252). Cape Town: Economic Research Southern Africa. Retrieved from https://ideas.repec.org/ $\mathrm{p} / \mathrm{rza} /$ wpaper/252.html

Boubaker, A., \& Sebai, S. (2009). Inter-market information flow: A non-linear approach. Applied Economics Letters, 16(10), 1009-1015. https://doi.org/10.1080/17446540 802345414

Breitung, J., \& Candelon, B. (2006, June). Testing for short-and long run causality: A frequency-domain approach. Journal of Econometrics, 132, 363-378. https:// doi.org/10.1016/j.jeconom.2005.02.004

Cheung, Y.-W., \& Ng, L. K. (1996, May-June). A causality-in-variance test and its application to financial market prices. Journal of Econometrics, 72, 33-48. https:// doi.org/10.1016/0304-4076(94)01714-X

Çevik, E. I., Çevik, N. K., \& Gurkan, S. (2012). Analyzing of relationship among stock markets of the U.S., Germany and Turkey with MS-VAR model. Journal of BRSA Banking and Financial Markets, 6(1), 133-155. Retrieved from https://ideas. repec.org/a/bdd/journl/v6y2012i1p133-155.html

Diebold, F. X., \& Nerlove, M. (1989). The dynamics of exchange rate volatility: A multivariate latent factor ARCH model. Journal of Applied Econometric, 4, 1-21. https://doi.org/10.1002/jae.3950040102

Diebold, F. X., \& Yilmaz, K. (2009, January). Measuring financial asset return and volatility spillovers with application to global equity markets. The Economic Journal, 119(534), 158-171. https://doi.org/10.1111/j.1468-0297.2008.02208.x

Dewandaru, G., Masih, R., \& Masih, M. (2017, September). Regional spillover across transitioning emerging and frontier equity markets: A multi-time scale wavelet analysis. Economic Modelling, 65, 30-40. https://doi.org/10.1016/j.econmod.2017. 04.026

El Abed, R., Boukadida, S., \& Jaidane, W. (2019). Financial stress transmission from sovereign credit market to financial market: A multivariate FIGARCH-DCC approach. Global Business Review, 20(5), 1122-1140. https//doi.org/10.1177/0972150 919846994

Engle, R. F. (1982). Autoregressive conditional heteroskedasticity with estimates of the variance of United Kingdom inflation. Econometrica, 50(4), 987-1007. https:// doi.org/10.2307/1912773 
Ekpo, A., \& Chuku, C. (2017). Regional financial integration and economic activity in Africa. Journal of African Economies, 26, 40-75. https://doi.org/10.1093/jae/ejx030

Feldman, R. A., \& Wagner, N. (2002). The financial sector, macroeconomic policy and performance. EIB Papers, 7(2), 13-30. Retrieved from http://hdl.handle.net/ $10419 / 44819$

Giovannetti, G., \& Velucchi, M. (2013). A spillover analysis of shock from US, UK and China on African financial markets. Review of Development Finance, 3(4), 169-179. https://doi.org/10.1016/j.rdf.2013.10.002

Gradojevic, N., \& Dobardzic, E. (2013). Causality between Regional Stock Markets: A frequency domain approach. Panoeconomicus, 60(5), 633-647, https://doi.org/ 10.2298/PAN1305633G

Granger, C. W. J. (1969, July). Investigating causal relations by econometric models and cross spectral methods. Econometrical, 37, 424-438. https://doi.org/10.2307/ 1912791

Granger, C. W. J. (1980). Testing for causality: A personal viewpoint. Journal of Economic Dynamics and Control, 2, 52-329. https://doi.org/10.1016/0165-1889(80) 90069-X

Grant, W., \& Wilson, G. K. (2012). The consequences of the global financial crisis: The rhetoric of reform and regulation. Oxford: Oxford University Press. https://doi.org/ 10.1093/acprof:oso/9780199641987.001.0001

Gumede, V., Oloruntoba, S. O., \& Kamga, S. D. (2020). Regional integration and migration in Africa: Lessons from Southern and West Africa. https://doi.org/ $10.1163 / 9789004411227$

Guo, B., \& Ibhagui, O. (2019). China-Africa stock market linkages and the global financial crisis. Journal of Asset Management, 20, 301-316. https://doi.org/10.1057/ s41260-019-00122-8

Hafner, C. M., \& Herwartz, H. (2006, September). A Lagrange multiplier test for causality in variance. Economic Letters, 93, 137-141. https://doi.org/10.1016/j.econlet. 2006.04.008

Hanabusa, K. (2009, May). Causality relationship between the prices of oil and economic growth in Japan. Energy Policy, 37(5), 1953-1957, https://doi.org/10.1016/ j.enpol.2009.02.007

Kang, S. H., \& Yoon, S.-M. (2020, April). Dynamic correlation and volatility spillovers across Chinese stock and commodity futures markets. International Journal of Finance and Economics, 25(2), 261-273. https://doi.org/10.1002/ijfe.1750

Kiliç, R. (2011). A conditional variance tale from an emerging economy's freely floating exchange rate. Applied Economics, 43(19), 2465-2480. https://doi.org/10.1080/ 00036840903266812

Marozva, G. (2017). Africa stock market cross-market linkages: A time-varying dynamic conditional correlations (DCC-GARCH) approach. Journal of Applied Business Research, 33(2), 321. https://doi.org/10.19030/jabr.v33i2.9904 
Mensi, W., Hammoudeh, S., Nguyen, D. K., \& Kang, S. H. (2016, March). Global financial crisis and spillover effects among the U.S. and BRICS stock markets. International Review of Economics and Finance, 42, 257-276. https://doi.org/10. 1016/j.iref.2015.11.005

Moon, G.-H., \& Yu, W.-C. (2010). Volatility spillovers between the US and China stock markets: Structural break test with symmetric and as symmetric GARCH approaches. Global Economic Review, 39(2), 129-149. https://doi.org/10.1080/ 1226508X.2010.483834

Nishimura, Y., Tsutsui, Y., \& Hirayama, K. (2016, September). The Chinese stock market does not react to the Japanese market: Using intraday data to analyzed return and volatility spillover effects. Japanese Economic Review, 67(3), 280-294. https://doi.org/10.1111/jere.12086

Nelson, D. B. (1991, March). Conditional heteroscedasticity in asset returns: A new approach. Econometrical, 59(2), 347-370. https://doi.org/10.2307/2938260

Onay, C., \& Ünal, G. (2012). Cointegration and extreme value analyses of Bovespa and Istanbul stock exchanges. https://doi.org/10.2139/ssrn.1636183

Osabuohien-Irabor, O. (2015). Impact of oil price shock on foreign currency and stock markets: The Nigeria perspective. Journal of Applied Science, Engineering and Technology, 15(1), 34-42.

Osabuohien-Irabor, O. (2020). Investors' attention: Does it impact the Nigerian stock market activities. Journal of Economics and Development, 23(1), 59-76. https:// doi.org/10.1108/JED-02-2020-0015

Phume, M. P., \& Bonga-Bonga, L. (2018). Return and volatility spillovers between South African and Nigerian equity market (Munich Personal RePEc Archive, No._87638). Retrieved from https://mpra.ub.unimuenchen.de/87638/1/MPRA_ paper_87638.pdf

Qiao, Z., Li, Y., \& Wong, W. K. (2011). Regime-dependent relationships among the stock markets of the US, Australia and New Zealand: A Markov switching VAR approach. Applied Financial Economics, 21(24), 1831-1841. Retrieved from http:// hdl.handle.net/10.1080/09603107.2011.595678

Ross, S. A. (1989, March). Information and volatility: The no-arbitrage martingale approach to timing and resolution irrelevancy. Journal of Finance, 44(1), 1-17. https://doi.org/10.2307/2328272

Ratanapakorn, O., \& Sharma, S. C. (2002). Interrelationships among regional stock indices. Review of Financial Economics, 11, 91-108, https://doi.org/10.1016/ S1059-0560(02)00103-X

Rashid, A. (2007, August). Stock prices and trading volume: An assessment for linear and nonlinear Granger causality. Journal of Asian Economics, 18(4), 595-612. https://doi.org/10.1016/j.asieco.2007.03.003

Sabkha, S., de Peretti, C., \& Mezzez Hmaied, D. (2019). International risk spill over in sovereign credit markets: An empirical analysis. Managerial Finance, 45(8), 1020 1040. https://doi.org/10.1108/MF-11-2017-0490 